\title{
Bioprospecting Aspergillus section Nigri in Atlantic Forest soil and plant litter
}

\section{Bioprospecção de Aspergilllus seção Nigri em solo e serrapilheira da Mata Atlântica}

\author{
Tatiana Faria Maia', Marcelo Elias Fraga* \\ | | | | | | | | | | | | | | | | | | | | | | | | | | | | | | | | | | | | | | | | | | | | | | | | | | | | | | | | | | | | | | | | | | | | | | | | | | | | | | | | | | | | | | | | | | | | | | | | | | | | | | | | | | | | | | | | | | | | | | | | | | | | | | | | | | | | | | | | | | | | | | | | | | | | | | | | | | | | | | | | | | | | | | | | | | | | | | | | | | | | | | | | | | | | | | | | | | | | | | |
}

\begin{abstract}
The use of fungi as a source of enzymes has become widespread in various industrial and commercial areas, and Aspergillus section Nigri has significant potential for producing enzymes. The aim of this study was to isolate Aspergillus section Nigri from plant litter and soil from the Atlantic Forest biome and evaluate it with regards to hydrolytic enzyme production. The trials for producing the enzymes were carried out in Petri dishes, using different culture mediums adapted for microbial growth and with the respective substrates for inducing enzyme production - cellulase (carboxymethyl cellulose), protease (skimmed milk), amylase (soluble starch), pectinase (citrus pectin), and phytase (Pikovskaya medium). Forty-two fungi were isolated, $16.7 \%$ derived from the plant litter layer and $83.3 \%$ derived from soil at a depth of 0 to $5 \mathrm{~cm}$ and 5 to $10 \mathrm{~cm}$. All of the isolated lineages presented amylase, protease, and phytase production, with $90.4 \%$ producing cellulase and no lineage producing pectinase. From the results, the significant potential for Atlantic Forest fungi as hydrolytic enzyme producers could be perceived. The enzymatic activity evaluations presented a satisfactory result when compared with the scientific literature.
\end{abstract}

KEYWORDS: filamentous fungi; enzymatic index; hydrolytic enzymes.
RESUMO: A utilização dos fungos como fonte de enzimas vem adquirindo status de destaque nas mais variadas áreas industriais e comerciais, e os Aspergillus membros da seção Nigri possuem significativo potencial para produçáo de enzimas. Os objetivos deste estudo foram isolar e avaliar Aspergillus da seçáo Nigri de serrapilheira e solos do bioma Mata Atlântica quanto à produçáo de enzimas hidrolíticas. Os ensaios para produção das enzimas foram realizados em placas de Petri, utilizando diferentes meios de cultivo, adequados ao crescimento microbiano e com a presença dos respectivos substratos indutores à produção das enzimas - celulases (carboximetilcelulose), proteases (leite desnatado), amilases (amido solúvel), pectinases (pectina cítrica) e fitase (meio Pikovskaya). Foram isolados 42 fungos, sendo desse total $16,7 \%$ provenientes da camada de serrapilheira e $83,3 \%$ provenientes do solo na profundidade de 0 a $5 \mathrm{~cm}$ e 5 a $10 \mathrm{~cm}$. Todas as linhagens isoladas apresentaram produçáo de amilases, protease $\mathrm{e}$ fitase, 90,4\% produziram celulase, e nenhuma linhagem produziu pectinase. Com esses resultados, percebeu-se significativo potencial dos fungos da Mata Atlântica como produtores de enzimas hidrolíticas. As avaliações da atividade enzimática apresentaram resultado satisfatório quando comparados à literatura científica.

PALAVRAS-CHAVE: fungos filamentosos; índice enzimático; enzimas hidrolíticas.

\footnotetext{
'Instituto de Ciências Biológicas e da Saúde, Universidade Federal Rural do Rio de Janeiro (UFRRJ) - Seropédica (RJ), Brazil.

'Laboratório de Biologia de Fungos, Instituto de Veterinária, UFRRJ - Seropédica (RJ), Brazil.

*Corresponding author: fraga@ufrrj.br

Received on: 06/16/2015

Accepted on: 10/05/2016
} 


\section{INTRODUCTION}

Brazil contains the greatest biodiversity on the planet. Among the country's various biomes, the Atlantic Forest features as one of the 34 global "hotspots". Its climatic conditions enable the existence of microorganisms that decompose and degrade forest biomass, making the soil in this biome very rich in nutrients. Among these microorganisms, fungi are of crucial importance to the functioning of this ecosystem.

Fungi of the Aspergillus genus are filamentous, cosmopolitan, saprophytes, and are mainly found in regions with tropi$\mathrm{cal}$ and subtropical climates (KLICH, 2002). Some species of this genus are used in biotechnology, in which they produce a diversity of biocompounds such as antibiotics, microtoxins, enzymes, organic acids, and phenolic compounds, among other substances (DAGENAIS; KELLER, 2009).

Aspergillus stands out as being the most important genus for the commercial production of extracellular enzymes (NOVAKI, 2009), the most widely used species being Aspergillus flavus, A. niger, A. awamori, A. oryzae, A. nidulans, A. fumigatus, $A$. clavatus, A. glaucus, A. ustus, and A. versicolor (SLIVINSKI, 2007). Also in this genus, the species from the Nigri section have been extensively studied, as they are good producers of enzymes such as amylase, cellulose, pectinase, protease, and phytase (SALES et al., 2010; RODRÍGUEZ et al., 2011; REZENDE et al., 2012; MACIEL, 2013).

The use of these fungi as enzyme producers is recognized by the Food and Drug Administration (FDA), from the United States, and the products derived can be used for safe human consumption (SAID; PIETRO, 2002). Thus, some species of the Aspergillus genus have a Generally Recognized as Safe (GRAS) status, due to their low toxicity and historic use in the preparation and production of foods and drinks (ABARCA et al., 2004).

Enzymatic technology is being used to obtain advantages in establishing a technologically clean process, in which hydrolytics are produced by different species of Aspergillus, with a broad diversity regarding the characteristics of these enzymes, enhancing their application in different industry sectors, such as the textile, pulp and paper, pharmaceutical, and especially food industries (BARATTO et al., 2011).

The main sectors that use a large number of these enzymes are the food and drink sectors, in which amylase and cellulase enzymes are used in preparing the mash for producing beer. In baking, amylase and peptidase enzymes are used to facilitate the manipulation of dough. Peptidase is mainly used in processing fruit juices and wines, and in the treatment of silage along to phytase, as it improves nutritional quality and facilitates digestion by ruminant and monogastric animals (PANDEY et al., 2005; UENOJO; PASTORE, 2007; BECKER et al., 2009).

Therefore, studies have focused on selecting new fungi as a source of new enzymes, exploring the biotechnological potential of global biodiversity (ABBASI et al., 2011; RODRÍGUES et al., 2011; MACIEL, 2013). The inoculation technique is used as a way of selecting, with Petri dishes and a solid medium containing a source of enzymatic activity induction, such as starch, pectin, skimmed milk, calcium phosphate, and carboxymethyl cellulose (GOPINATH et al., 2005).

Considering the little knowledge regarding the fungi found in areas of the Atlantic Forest, the importance of studies that contribute to expanding the data on fungi diversity in this threatened biome is clear, as well as the use of these fungi in biotechnological processes.

\section{MATERIAL AND METHODS}

\section{Plant Litter and Soil Sampling}

The plant litter and soil sample collection areas are located in the central west of Minas Gerais state, in the municipality of Sete Lagoas.

The plant litter and soil samples were collected in two periods: the first wet, at the end of January, and the second dry, at the beginning of September. Nine forest fragments were sampled, with the sampling carried out at three depths (plant litter, 0 to $5 \mathrm{~cm}$, and 5 to $10 \mathrm{~cm}$ ), with three repetitions for each depth, thus totaling 162 samples. After collection, the packages with the samples were stored at $4^{\circ} \mathrm{C}$ until analysis.

\section{Isolating the fungal lineages}

The isolations were carried out using five grams of soil and plant litter resuspended in a Erlenmeyer flask with $45 \mathrm{~mL}$ of $0.1 \%$ peptone containing $0.1 \%$ Tween 80 , then shaken for $30 \mathrm{~min}$ in a vertical rod homogenizer at $150 \mathrm{rpm}$. The culture medium used was Dicloran Rosa de Bengal Cloranfenicol (DRBC), with $0.1 \mathrm{~mL}$ doses of the respective dilutions $\left(10^{2}\right.$ to $10^{\circ}$ ), incubated in ovens at $25^{\circ} \mathrm{C}$ for five to seven days (FRAGA; PEREIRA, 2012).

\section{Morphological analyses of the isolated lineages}

The morphological identification was carried out based on a suspension of Aspergillus section Nigri spores in a solution containing $0.2 \%$ agar and $0.05 \%$ Tween 80 . From the suspension, $0.2 \mathrm{~mL}$ was used for inoculation at three equidistant points in the Petri dish containing the Czapek Yeast Agar (CYA) and Malt Extract Agar (MEA) culture mediums, in triplicate for each medium.

The incubation was carried out at 25 and $37^{\circ} \mathrm{C}$ for the dishes containing the CYA medium and $25^{\circ} \mathrm{C}$ for the MEA medium. After an inoculation period of seven days, their 
macroscopic (color of surface and back of the colony, colony diameter, presence or absence and color of sclerotia) and microscopic (vesicle diameter and form, phialide length and width, color, size, form and texture of the conidia, and color of the hyphae) characteristics were analyzed. Inoculations were also carried out in Petri dishes containing MEA medium for 10 days to verify growth at temperatures of $15,33,36$, and $40^{\circ} \mathrm{C}$ (KLICH, 2002; SAMSON et al., 2004; SAMSON et al., 2007; VARGA et al., 2011; MEIJER et al., 2011).

\section{Enzymatic index of the lineages}

The enzymatic index (EI) is one of the parameters used in order to evaluate the production of enzymes by microorganisms in a solid medium. For the microorganisms considered enzyme producers, there is a direct correlation between the diameter of the halo of degradation and their degradative ability (LIN et al., 1991). In this context, the Aspergillus section Nigri isolates were evaluated as producers of cellulose, peptidase, amylase, phytase, and pectinase. Inoculation of the lineages was carried out in dishes containing the mediums, in a $10^{4}$ spores $/ \mathrm{mL}$ concentration, and incubated for five days at $25^{\circ} \mathrm{C}$.

To detect the enzymes, the cellulase activity was evaluated using the synthetic medium containing carboxymethyl cellulose (CMC) as the only source of carbon, the composition being in accordance with RUEGGER; TAUK-TORNISIELO (2004). After the incubation period, the revelation of the halo of hydrolysis was carried out by adding $10 \mathrm{~mL}$ of Red Congo coloring solution $(2.5 \mathrm{~mL}$ in a Tris buffer $0.1 \mathrm{M}, \mathrm{pH}$ 8) over each colony, removing the solution after $30 \mathrm{~min}$ and washing the cultures in $5 \mathrm{~mL}$ of $\mathrm{NaCl} 0.5 \mathrm{M}$ solution in this same buffer, for $15 \mathrm{~min}$. Carboxymethyl cellulose degradation around the fungal colony is detected via the formation of a yellow halo around the colony (POINTING, 1999).

The degradation capacity of the amylase and pectinase was verified in accordance with HANKIN; ANAGNOSTAKIS (1975). The amylolytic activity was detected after the addition of $5 \mathrm{~mL}$ of an iodine solution over each colony. Formation of a yellow zone around the fungal colony and the development of petrol blue coloring on the remaining surface of the Petri dish indicate the occurrence of starch hydrolysis. The pectinolytic activity was verified after adding the chloridric acid solution (HCL) $5 \mathrm{~N}$, for $5 \mathrm{~min}$.

The degradation capacity of the peptidase was verified in accordance with GOPINATH et al. (2005).

Pikovskaya Medium (PIKOVSKAYA, 1948) was used to evaluate the productive capacity of the phytase. The halo indicating the production of peptidase and phytase enzymes can be seen without a revealing solution, with a clear zone being detected around the colonies.

The colony diameters and halos produced were measured with a pachymeter (NOGUEIRA; CAVALCANTI, 1996). The enzymatic index (EI) was calculated by the ratio between the average diameter of the halo of degradation and the average diameter of the colony, as proposed by STAMFORD et al. (1998).

\section{Statistical Analysis}

The experiment was conducted in an entirely randomized design (ERD). All of the tests were carried out with three repetitions, in accordance with the number of positive treatments for each enzyme. The data obtained were submitted for analysis of variance, using the Sisvar software (FERREIRA, 2000). The averages of the treatments were compared using the Scott-Knott test at a 5\% level of probability.

\section{RESULTS AND DISCUSSION}

In this perspective, 1,854 fungal lineages from the plant litter and soil samples were isolated, 907 lineages in the wet period and 947 lineages in the dry period. Of this total number of isolates, 42 were Aspergillus section Nigri, 16.7\% derived from the plant litter layer and $83.3 \%$ derived from soil at depths of 0 to $5 \mathrm{~cm}$ and 5 to $10 \mathrm{~cm}$.

In order to evaluate the cellulase production potential, it was observed that, of the lineages isolated from Aspergillus section Nigri, 38 of them produced cellulase; that is, $90.4 \%$ presented a halo of hydrolysis. The statistical analysis of the cellulose production showed that there was a difference between the enzymatic indices of the isolates analyzed, forming three different groups (a-c). Four isolates stood out from the rest in relation to the enzymatic index: $A$. aculeatus, 42 with 1.36; A. aculeatus, 13 with 1.37; $A$. aculeatinus, 9; and $A$. aculeatus, 36 with 1.38 , and those that presented a negative result were the $A$. niger aggregates (Table 1 ).

According to RUEGGER; TAUK-TORNISIELO (2004), enzymatic indices of around 1.6 are values found in fungi of the Aspergillus sp. genus, in which this index can be used as a useful measure for selecting lineages within the same species. These same authors evaluated the cellulase activity of fungi isolated from soil and observed that $45 \%$ of the isolates presented positive activity, since there was formation of a halo, indicating degradation of the medium; however, the $A$. niger species obtained an EI value of 1.4, close to the values found in our study for species of the Nigri section.

FERNANDES (2009) tested 24 fungal lineages isolated from various sources in order to detect cellulase, among which nine belonged to the Aspergillus section Nigri genus: A. carbonarius, $\mathrm{EI}=1.4$ and 1.14; $A$. niger, $\mathrm{EI}=1.10$ and 1.27; $A$. foetidus, $\mathrm{EI}=1.13$ and 1.16; $A$. niger aggregates, $\mathrm{EI}=1.11$, where these last EI values were close to those ones found in this study. AGUSTINI et al. (2012) also carried out a qualitative test of cellulase production, using the CMC medium in 553 isolates, containing fungi and bacteria, and found the 
Table 1. Evaluation of the lineages of Aspergillus section Nigri isolated from the plant litter and soil, by their respective Enzymatic Indices.

\begin{tabular}{|c|c|c|c|c|c|c|c|c|c|}
\hline \multirow{2}{*}{ Aspergillus Isolates } & \multicolumn{3}{|c|}{ Cellulase } & \multicolumn{3}{|c|}{ Peptidase (Protease) } & \multicolumn{3}{|c|}{ Amylase } \\
\hline & $\varnothing c$ & Øh & E.I.* & $\varnothing c$ & Øh & E.I.* & $\varnothing c$ & $\varnothing \mathrm{h}$ & E.I.* \\
\hline O2 A. aculeatus & 2.57 & 3.30 & $1.29^{b}$ & 6.5 & 7.83 & $1.20^{d}$ & 4.1 & 4.8 & $1.16^{b}$ \\
\hline 03 A. aculeatus & 2.90 & 3.63 & $1.25^{b}$ & 5.57 & 7.5 & $1.25^{c}$ & 3.2 & 3.8 & $1.22^{a}$ \\
\hline O4 A. aculeatinus & 3.63 & 4.10 & $1.13^{c}$ & 6.87 & 8.33 & $1.21^{d}$ & 4.1 & 4.8 & $1.16^{b}$ \\
\hline $05 \mathrm{~A}$. aculeatinus & 3.60 & 4.27 & $1.18^{c}$ & 6.77 & 8.7 & $1.28^{c}$ & 4.1 & 5.2 & $1.28^{a}$ \\
\hline 06 A. aculeatinus & 3.63 & 4.30 & $1.18^{c}$ & 7.5 & 8.83 & $1.17^{\mathrm{e}}$ & 4.8 & 6.1 & $1.26^{\mathrm{a}}$ \\
\hline O7 A. aculeatinus & 3.80 & 4.47 & $1.17^{c}$ & 7.2 & 8.73 & $1.21^{\mathrm{d}}$ & 4.5 & 5.3 & $1.16^{b}$ \\
\hline O8 A. aculeatus & 3.13 & 3.87 & $1.24^{b}$ & 6.17 & 7.3 & $1.18^{\mathrm{e}}$ & 3.9 & 4.8 & $1.22^{a}$ \\
\hline O9 A. aculeatinus & 2.63 & 3.57 & $1.38^{a}$ & 7.03 & 8.5 & $1.21^{\mathrm{d}}$ & 4.1 & 4.9 & $1.21^{\mathrm{a}}$ \\
\hline 10 A. aculeatus & 3.27 & 3.93 & $1.20^{c}$ & 6.47 & 8 & $1.23^{c}$ & 3.6 & 4.5 & $1.24^{\mathrm{a}}$ \\
\hline 11 A. aculeatus & 3.33 & 4.27 & $1.28^{b}$ & 5.93 & 7.27 & $1.22^{\mathrm{d}}$ & 3.8 & 4.4 & $1.17^{b}$ \\
\hline 12 A. aculeatus & 3.00 & 3.53 & $1.18^{c}$ & 6.83 & 8.1 & $1.18^{\mathrm{e}}$ & 4.5 & 5.3 & $1.18^{b}$ \\
\hline 13 A. aculeatus & 2.57 & 3.50 & $1.37^{a}$ & 5.53 & 7.1 & $1.29^{c}$ & 4.0 & 4.7 & $1.16^{b}$ \\
\hline 14 A. aculeatus & 3.23 & 3.77 & $1.17^{c}$ & 5.63 & 7.1 & $1.26^{c}$ & 3.8 & 4.7 & $1.23^{a}$ \\
\hline 15 A. aculeatinus & 3.83 & 4.30 & $1.12^{c}$ & 6.97 & 8.5 & $1.22^{d}$ & 4.2 & 5.3 & $1.25^{\mathrm{a}}$ \\
\hline 16 A. aculeatus & 2.80 & 3.67 & $1.31^{b}$ & 6.07 & 7.33 & $1.21^{d}$ & 4.2 & 4.9 & $1.18^{b}$ \\
\hline 17 A. aculeatus & 3.37 & 4.03 & $1.20^{c}$ & 5.7 & 6.77 & $1.18^{\mathrm{e}}$ & 3.2 & 3.9 & $1.23^{a}$ \\
\hline 18 A. aculeatus & 3.23 & 4.17 & $1.29^{b}$ & 5.37 & 6.77 & $1.26^{\mathrm{e}}$ & 4.0 & 4.8 & $1.18^{b}$ \\
\hline $20 \mathrm{~A}$. aculeatinus & 3.30 & 4.17 & $1.26^{b}$ & 7.03 & 8.77 & $1.24^{c}$ & 4.2 & 5.3 & $1.25^{a}$ \\
\hline 21 A. aculeatinus & 3.30 & 4.17 & $1.26^{b}$ & 7.03 & 8.77 & $1.25^{c}$ & 3.6 & 4.5 & $1.26^{a}$ \\
\hline 22 A. aculeatinus & 3.60 & 4.07 & $1.13^{c}$ & 6.9 & 8.83 & $1.28^{c}$ & 4.6 & 5.6 & $1.23^{a}$ \\
\hline 23 A. aculeatus & 3.07 & 3.80 & $1.24^{b}$ & 5.6 & 6.73 & $1.20^{d}$ & 3.5 & 4.4 & $1.27^{\mathrm{a}}$ \\
\hline $24 \mathrm{~A}$. aculeatinus & 3.03 & 3.50 & $1.15^{c}$ & 6.67 & 8 & $1.20^{d}$ & 3.5 & 4.1 & $1.19^{b}$ \\
\hline 25 A. aculeatus & 3.53 & 4.27 & $1.21^{c}$ & 5.43 & 6.77 & $1.24^{c}$ & 3.9 & 4.6 & $1.19^{b}$ \\
\hline 26 A. aculeatus & 3.57 & 4.10 & $1.15^{c}$ & 6.47 & 7.53 & $1.16^{\mathrm{e}}$ & 4.6 & 5.2 & $1.14^{\mathrm{b}}$ \\
\hline 28 A. aculeatinus & 2.77 & 3.50 & $1.28^{b}$ & 7.07 & 8.73 & $1.23^{c}$ & 4.6 & 5.7 & $1.24^{a}$ \\
\hline 29 A. aculeatus & 3.57 & 4.43 & $1.24^{b}$ & 6.6 & 7.67 & $1.16^{\mathrm{e}}$ & 4.2 & 4.9 & $1.18^{b}$ \\
\hline 31 A. aculeatinus & 3.53 & 4.27 & $1.21^{c}$ & 6.73 & 8.27 & $1.22^{\mathrm{d}}$ & 3.5 & 4.3 & $1.25^{a}$ \\
\hline $32 \mathrm{~A}$. aculeatus & 3.63 & 4.10 & $1.13^{c}$ & 5.57 & 6.83 & $1.23^{d}$ & 4.0 & 4.7 & $1.17^{\mathrm{b}}$ \\
\hline 33 A. aculeatus & 3.17 & 3.90 & $1.23^{b}$ & 5.8 & 7.27 & $1.25^{c}$ & 3.9 & 4.6 & $1.19^{b}$ \\
\hline 34 A. aculeatus & 3.40 & 4.27 & $1.25^{b}$ & 6.83 & 8.1 & $1.18^{c}$ & 4.0 & 4.9 & $1.23^{a}$ \\
\hline 35 A. aculeatus & 3.57 & 4.23 & $1.19^{c}$ & 6.97 & 8.17 & $1.17^{\mathrm{e}}$ & 3.3 & 3.9 & $1.20^{b}$ \\
\hline 36 A. aculeatus & 2.67 & 3.67 & $1.38^{a}$ & 6.33 & 8 & $1.26^{c}$ & 4.4 & 5.3 & $1.19^{b}$ \\
\hline 37 A. aculeatus & 3.33 & 4.07 & $1.22^{c}$ & 5.43 & 6.77 & $1.24^{c}$ & 3.5 & 4.4 & $1.25^{\mathrm{a}}$ \\
\hline 38 A. aculeatus & 3.57 & 4.33 & $1.21^{c}$ & 6 & 7.27 & $1.21^{\mathrm{d}}$ & 4.0 & 4.7 & $1.17^{\mathrm{b}}$ \\
\hline 39 A. aculeatus & 3.63 & 4.30 & $1.18^{c}$ & 5.63 & 7.1 & $1.26^{c}$ & 3.6 & 4.5 & $1.24^{\mathrm{a}}$ \\
\hline 40 A. aculeatus & 3.70 & 4.37 & $1.18^{c}$ & 6.67 & 7.73 & $1.15^{\mathrm{e}}$ & 4.2 & 4.8 & $1.16^{b}$ \\
\hline 41 A. aculeatus & 3.43 & 4.37 & $1.27^{\mathrm{b}}$ & 6.07 & 7.07 & $1.16^{\mathrm{e}}$ & 3.8 & 4.7 & $1.23^{a}$ \\
\hline 42 A. aculeatus & 3.10 & 4.23 & $1.36^{\mathrm{a}}$ & 5.37 & 6.77 & $1.26^{c}$ & 4.7 & 5.8 & $1.22^{a}$ \\
\hline \multicolumn{10}{|l|}{ Aggregates } \\
\hline 01 A. niger & - & - & - & 5.3 & 7.43 & $1.40^{a}$ & 3.7 & 4.3 & $1.18^{b}$ \\
\hline 19 A. niger & - & - & - & 6.1 & 8.17 & $1.34^{\mathrm{b}}$ & 4.2 & 5.2 & $1.26^{a}$ \\
\hline 27 A. niger & - & - & - & 6 & 8.35 & $1.40^{a}$ & 3.9 & 5.0 & $1.28^{a}$ \\
\hline 30 A. niger & - & - & - & 6.2 & 8.33 & $1.34^{\mathrm{a}}$ & 4.5 & 5.6 & $1.25^{\mathrm{a}}$ \\
\hline
\end{tabular}

Øc: colony diameter (cm); Øh: halo diameter (cm); El: enzymatic index; (-): did not grow and/or did not produce a halo; a, b, c: similarity of enzymatic index, in which same letters similar results. 
A.s niger species to be a cellulase producer, in which the respective indices varied from 1 to 3.36 for all of the microorganisms.

MONTEIRO et al. (2012) selected cellulase producing isolates belonging to the Aspergillus and Penicillium genera, and, of the 135 isolates tested, only 20 were producers, and the five isolates that stood out with regards to qualitative production of cellulase belong to the Aspergillus genus.

With regards to protease production, a significant difference between the averages analyzed can be observed in Table 1 , with the separation of five different groups (a-e) occurring with a variation in $\mathrm{EI}$ of between 1.15 and 1.40. The isolates that presented the highest indices were the fungi from the $A$. niger aggregate group, with $\mathrm{EI}=1.40$ and 1.34. None of the isolates presented a negative result.

In papers from FERNANDES (2009) and SCHUSTER et al. (2002), A. niger did not produce a halo of degradation indicative for proteolytic determination, unlike in this study, in which the Nigri section species produced a halo of degradation, although with EI $\leq 2.0$. PEREIRA (2012) also observed protease enzyme production when analyzing 40 isolates belonging to the Ecocenter Fungi Collection/Empresa de Pesquisa Agropecuária de Minas Gerais (EPAMIG) and the Microtoxins and Mycology Laboratory of Universidade Federal de Lavras (UFLA), of which six belonged to the Aspergillus genus and presented the same results, $\mathrm{EI} \leq 2.0$, with there being no higher values for this genus. On the other hand, SOHAIL et al. (2009) obtained $81 \%$ protease producing fungi in 160 isolates, and among these the $A$. niger and A. flavus species were considered potential producers of proteolytic enzymes.

In the evaluation of the potential production of the amylase enzyme, $100 \%$ presented a halo of hydrolysis, the results of which are presented in Table 1 . There was a small difference between the averages, forming two groups ( $\mathrm{a}$ and $\mathrm{b}$ ); however, there was no isolate that stood out. All the results indicated that the lineages tested are able to degrade the starch present in the culture medium, but no lineage presented enzymatic potential, since they did not reach $\mathrm{EI} \geq 2.0$.

TEIXEIRA (1994) found that the greatest halos of enzymatic activity were produced by $A$. niger for amylases, cellulases, and pectinases. MORAES (2004) also observed that $A$. niger was able to degrade $\alpha$-amylase. However, these results were not similar to those obtained in this study.

SILVA et al. (2006) did not find amylolytic activity in 29 Aspergillus isolates. When analyzing mutant lineages of the Aspergillus nidulans fungus, FLORES et al. (2010) observed little halos, smaller than 2.0. PEREIRA (2012) also studied the Aspergillus genus for amylase production; however, they were not producers of this enzyme using the methodologies tested. Thus, these papers partly support the results presented in this study, since they affirm that amylase production by Aspergillus in a solid culture medium may not be positive or involve little amylolytic activity.

All of the isolates in this paper presented growth in the selective medium for phytase, with an average colony diameter of $70 \mathrm{~mm}$; however, a halo of degradation was not formed, and it was, therefore, not possible to measure the enzymatic indices of the Aspergillus section Nigri isolates.

The non formation of a halo of degradation may be due to the extensive growth of the fungus in this culture medium, after five days of incubation, as the fungus presented a colony with a diameter close to the size of the Petri dish. However, according to CASTRO; PEREIRA (2010), visualization of a halo depends on various factors, besides the composition of the culture medium, and some chemical substances can interfere in the coloring, leading to false-positives or even causing its precipitation or inhibiting the link between it and the polysaccharides.

The 42 lineages did not grow and did not present a halo of hydrolysis indicating pectinase activity.

PEREIRA (2012) tested two methodologies for producing pectinase. For the first one, there was low sensitivity to detecting the enzyme, with low results occurring, in which the EI values of the Aspergillus fungi were between 1.3 and 1.6, compared with the second methodology, in which the EI was between 1.6 and 4.8. However, just as in the results obtained in this study, the mentionated papers showed little or no pectinase activity for fungi of the Aspergillus genus. This was unlike the studies carried out by SANDRI (2010), which evaluated 60 fungal isolates from $A$. niger and $A$. oryzae with regards to the formation of a halo of pectin degradation in a solid medium, a qualitative test, and subsequent production by fermentation. The data showed that of the 30 Aspergillus niger isolates only six did not form a halo of hydrolysis, and the EI value varied from 1.2 to 2.8 .

It should be highlighted that the ability of a fungus to produce enzymes varies between species, as it also does between isolates from the same species, and it is quite variable. Innumerous factors of a biological and physical-chemical nature, such as $\mathrm{pH}$ and temperature, can influence the number and enzymatic activity of the microorganisms. The absence of activity, as occurred with the pectinase enzyme, may be attributed to the incapacity for secretion, to the direction of production to the intracellular metabolism, or to the insufficiency of the detection methods.

\section{CONCLUSION}

The results showed significant potential for Atlantic Forest fungi as producers of hydrolytic enzymes. All isolated lineages presented amylase, protease, and phytase production, with $90.4 \%$ producing cellulase and no lineage producing pectinase. The quantitative evaluations of enzymatic activity presented satisfactory results, and a quantitative evaluation is needed with regards to the potential of these fungi as producers of hydrolytic enzymes. 


\section{REFERENCES}

ABARCA, M.L.; ACCENSI F, C.J.; CABAÑES, F.J. Taxonomy and significance of black Aspergilli. Antonie Van Leeuwenhoek, v.86, p.33-49, 2004.

ABBASI, H.; SHAFIGHZADEH, H.; RAHIMI, A. Continuous production of polygalacturonases (PGases) by Aspergillus awamori using wheat flour in surface culture fermentation. Iranian Journal of Biotechnology, v.9, n.1, p.1-6, 2011.

AGUSTINI, L.; EFIYANTI, L.; FAULINA, S.A.; SANTOSO, E. Isolation and Characterization of Cellulase and Xylanase-Producing Microbes Isolated from Tropical Forests in Java and Sumatra. International Journal of Environment and Bioenergy, Florida, USA, v.3, n.3, p.154-167, 2012.

BARATTO, C.M.; SALAMONI, S.P.; COSTA, R.; OLIVEIRA, C.B.; LOCATELLI, G.O. Seleção de microrganismos produtores de enzimas hidrolíticas isolados da região do meio oeste de Santa Catarina, Brasil. Evidência, Joaçaba, v.11, n.2, p.1528,2011

BECKER, N.B.; BARATTO, C.M.; GELINSKI, J.M.L.N. Propriedades das enzimas $\alpha$-amilase e xilanase comerciais e sua influência na reologia da massa e na qualidade do pão de forma. Evidência, Joaçaba, v.9, n.1-2, p.67-82, 2009.

CASTRO, A.M.; PEREIRA JR., N. Produção, propriedades e aplicação de celulases na hidrólise de resíduos agroindustriais. Química Nova, v.33, p.1-12, 2010.

DAGENAIS, T.R.T.; KELLER, N.P. Pathogenesis of Aspergillus fumigatus in invasive aspergillosis. Clinical Microbiology Reviews, v.22, n.3, p.447-465, 2009.

FERREIRA, D.F. Sistemas de análise estatística para dados balanceados. Lavras: UFLA/DEX/SISVAR, 2000. $145 \mathrm{f}$.

FERNANDES, A.P. Avaliação do potencial enzimático de fungos filamentosos isolados de diferentes fontes. 2009. 58f. Dissertação (Mestrado em Ciências dos Alimentos) - Universidade Federal de Lavras, Lavras, 2009.

FLORES, A.C.; ZANETTIN, L.; PIN, H.K.; MENDONÇA, M.M.; BARCELOS, R.P.; TREVISOL, L.R.; CARVALHO, R.D.; SCHAUREN, D.; ROCHA, C.L.M.S.C.; BARONI, S. Identification of the amylolytic potential of mutant strains of the filamentous fungi Aspergillus nidulans. Ciência e Tecnologia de Alimentos, Campinas, v.30, n.3, p.700-705, 2010.

FRAGA, M.E.; PEREIRA, M.G. Diversidade de Trichocomaceae Isolada de Solo e Serrapilheira de Floresta Atlântica. Floresta e Ambiente, v.19, n.4, p.405-413, 2012.

GOPINATH, S.C.B.; ANBU, P.; HILDA, A. Extracellular enzymatic activity profiles in fungi isolated from oil-rich environments. Mycoscience, v.46, n.2, p.119-126, 2005.

HANKIN, L.; ANAGNOSTAKIS, S.L. The use of media for detection of enzymes production by fungi. Mycologia, New York, v.67, n.3, p.597-607, 1975.
$\mathrm{KLICH}, \mathrm{M}$.A. Identification of Common Aspergillus Species. Amsterdam: Centraalbureau voor Schimmelautures; Netherlands: Ponsen e Looijen; Louisiana: United States Department of Agriculture, Agricultural Research Service, Southern Regional Research Center New Orleans, 2002. 116p.

LIN, J.E.; CHANG, D.C.N.; SHEN, G.J. Correlations among several screening methods used for identifying wood-decay fungi that can degrade toxic chemicals. Biotechniques, Natick, v.5, n.4, p.275-280, 1991.

MACIEL, M.H.C. Abordagem polifásica para identificação de linhagens de Aspergillus seção Nigri preservadas na micoteca URM e caracterização quanto a produção e purificação de poligalacturonases. 2013. 151f. Tese (Doutorado em Biologia de Fungos) - Universidade Federal de Pernambuco, Recife, 2013.

MEIJER, M.; HOUBRAKEN, J.A.M.P.; DALHUIJEN, R.A.; SAMSON, R.A.; VRIES, R.P. Growth and hydrolase profiles can be used as characteristics to distinguish Aspergillus niger and other black aspergilli. Studies in Mycology, v.69, p.19-30, 2011.

MONTEIRO, P.S.; MELO, R.R.; TAVARES, M.P.; FALKOSKI, D.L.; GUIMARÃES, V.M.; PEREIRA, O.L.; REZENDE, S.T. Otimização da produção, caracterização e avaliação da fitase de Rhizopus stolonifer na hidrólise de fitato em ração animal. Revista Brasileira de Agrociência, Pelotas, v.18, n.2-4, p.117-132, 2012.

MORAES, L.M.P. Amilases. In: SAID, S.; PIETRO, R. Enzimas como agentes biotecnológicos. Ribeirão Preto: Legis Summa, 2004.

MUELLER, G.M.; SCHMIT, J.P. Fungal biodiversity: what do we know? What can we predict? Biodiversity and Conservation, London, v.16, n. 1, p.1-5, 2007.

NOGUEIRA, E.B.S.; CAVALCANTI, M.A.Q. Cellulolytic fungi isolated from processed oats. Revista de Microbiologia, v.27, p.7-9, 1996.

NOVAKI, L. Produção, purificação e caracterização parcial da invertase obtida por fermentação em estado sólido de soja com Aspergillus casiellus. 2009. 56f. Dissertação (Mestrado em Engenharia Química) - Universidade Estadual do Oeste do Paraná, Centro de Engenharia e Ciências Exatas, Paraná, 2009.

PANDEY, A.; WEBVB, C.; SOCCOL, C.R.; LARROCHE, C. Enzyme Technology. New Delhi: Asiatech Publishers, 2005. 760p.

PEREIRA, V.M. Avaliação do potencial enzimático de fungos filamentosos e otimização da produção de celulases por Aspergillus sulphureus (Fresen.) Wehmer. 2012. $111 \mathrm{f}$. Dissertação (Mestrado em Microbiologia Agrícola) - Universidade Federal de Lavras, Lavras/MG, 2012.

PIKOVSKAYA, R.J. Mobilization of phosphorous in soil in connection with vital activity of some microbial species. Mikrobiologiya, New York, v.17, p.362-370, 1948.

POINTING, S.B. Qualitative methods for the determination of lignocellulolytic enzyme production by tropical fungi. Fungal Diversity, v.2, p.17-33, 1999. 
REZENDE, E.D.E.F.; COUTO, F.A.; BORGES, J.G.; DA SILVA, D.M.; BATISTA, L.R. Potencial enzimático e toxigênico de fungos isolados de grãos de café. Coffee Science, Lavras, v.8, n.1, p.69-77, 2012.

RODRIGUES, P.; SANTOS, C.; VENÂNCIO, A.; LIMA, N. Species identification of Aspergillus section Flavi isolates from Portuguese almonds using phenotypic, including MALDI-TOF ICMS, and molecular approaches. Journal of Applied Microbiology, v. 111 , p.877-892, 2011.

RUEGGER, M.J.S.; TAUK-TORNISIELO, S.M. Cellulase activity of fungi isolated from soil of the Ecological Station of Juréia-Itatins, São Paulo, Brazil. Revista Brasileira de Botânica, São Paulo, v.27, n.2, p.205-211, 2004.

SAID, S.; PIETRO, R. Enzimas de interesse industrial e biotecnológico. Rio de Janeiro: Eventos, 2002. $121 \mathrm{f}$.

SALES, M.R.; DE MOURA R.B.; PORTO, T.S.; DE MACEDO, G.R.; PORTO, A.L.F. Variáveis que influenciam a produção de celulases e xilanase por espécies de Aspergillus. Pesquisa Agropecuária Brasileira, Brasília, v.45, n.11, p.1290-1296, 2010.

SAMSON, R.A.; HOUBRAKEN, J.A.M.P.; KUIJPERS, A.F.A.; FRANK, J.M.; FRISVAD, J.C. New ochratoxin A or sclerotium producing species in Aspergillus section Nigri. CBS Centenary: 100 Years of Fungal Biodiversity and Ecology. Studies in Mycology, v.5, p.45-61, 2004.

SAMSON, R.A.; NOONIM, P.; MEIJER, M.; HOUBRAKEN, J.A.M.P.; FRISVAD, J.C.; VARGA, J. Diagnostic tools to identify black Aspergilli. Studies in Mycology, v.59, p. 129-145, 2007.

SANDRI, I.G. Enzimas pectinolíticas: seleção de linhagens fúngicas produtoras, caracterização e aplicação em processos da indústria de alimentos. 2010. 114f. Tese (Doutorado em Biotecnologia) - Universidade de Caxias do Sul, Centro de Ciências Agrárias e Biológicas, Caxias do Sul, 2010.
SCHUSTER, E.; DUNN-COLEMAN, N.; FRISVAD, J.C.; DIJCK, P.W.M. van. On the safety of Aspergillus niger: a review. Applied Microbiology \& Biotechnology, Berlin, n.59, n.4-5, p.426-435, 2002.

SILVA, R.L.O.; LUZ, J.S.; SILVEIRA, E.B.; CAVALCANTE, U.M.T. Endophytic fungi of Annona spp.: isolation, enzymatic characterization of isolates and plant growth promotion in Annona squamosa L. seedlings. Acta Botanica Brasilica, Porto Alegre, v.20, n.3, p.649-655, 2006.

SLIVINSKI, C.T. Produção, purificação parcial e caracterização bioquímica de glucoamilase de Aspergillus niger obtida por fermentação em estado sólido. 2007. 128f. Dissertação (Mestrado em Ciência e Tecnologia de Alimentos) - Universidade Estadual de Ponta Grossa, Ponta Grossa/PR, 2007.

SOHAIL, M.; NASEEB, S.K.; SHERWANI, S.; SULTANA, S.; SHEHZAD, A.; AHMED, A.; SALEEM, S.; KHAN, S.A. Distribution of hydrolytic enzymes among native fungi: Aspergillus the pre-dominant genus of hydrolase producer. Pakistan Journal Botany, Lahone, v.41, n.5, p.2567-2582, 2009.

STAMFORD, T.L.M.; ARAÚJO, J.M.; STAMFORD, N.P. Enzymatic Activity of microorganisms isolated from yam bean legume (Pachyrhizus erosus L. Urban) (Pachyrhizus erosus L. Urban). Ciência e Tecnologia de Alimentos, v. 18, p.382-385, 1998.

TEIXEIRA, M.F.S. Obtenção de espécies de Aspergillus e Penicillium termofílicas e termotolerantes na Amazônia e caracterização de suas enzimas de interesse na indústria de alimentos. 1994. 85f. Dissertação (Mestrado em Tecnologia de Alimentos) - Universidade Federal do Amazonas, Instituto Nacional de Pesquisa da Amazônia, Manaus, 1994.

UENOJO, M.; PASTORE, G.M. Pectinases: aplicações industriais e perspectivas. Química Nova, v.30, n.2, p.388-394, 2007.

VARGA, J.; FRISVAD, J.C.; KOCSUBÉ, S.; BRANKOVICS, B.; TÓTH, B.; SZIGETI, G.; SAMSON, R.A. New and revisited species in Aspergillus section Nigri. Studies in Mycology, v.69, p. 1-17, 2011. 